\title{
Risk and Vulnerability of Migrant Labours from West Bengal and their Life Satisfaction during Pandemics of COVID-19: A Case Study
}

\author{
Md. Mustaquim ${ }^{1}$ and Woheeul Islam ${ }^{2}$ \\ ${ }^{1}$ Assistant Professor, Department of Geography, Aliah University, Kolkata, India \\ ${ }^{2}$ Research Scholar, Department of Geography, Aliah University, Kolkata, India \\ E-mail: mustaquim.md@gmail.com,Woheeul.islam@gmail.com
}

\begin{abstract}
From the very beginning of human evolution, people start the migration. Over time due to the complexity of life and rapid transform of socio-economic situation migration is gaining importance in day to day life. Migration is defined broadly as a permanent or semi-permanent change of residence. Migration takes place from economically less developed places to better places. West Bengal ranks fourth among states from where people out-migrated. West Bengal has a 9 crore population an estimation says from 2011 census data 2.2 lakh people, had migrated from West Bengal to other states for work and employment. As per our data Fifty per cent, migrants are lives in three sate namely Mumbai, Rajasthan and Tamil Nadu. Generally, they are blue caller workers that are urban natives are heated to do. They engaged in 3d jobs Dirty, dangerous and demeaning. We have collected the data of 5449 peoples of West Bengal over the different state from the secondary data source. During this outbreak of infectious diseases COVID-19 some restriction is imposed in daily routine social distancing norms are used to prevent the spreading of this disease. Due to sudden announcement of lockdown, they are jobless, homeless and hopeless. The analysis in the paper also indicates that $73 \%$ of migrant worker don't have basic food for surveillance. $12 \%$ of people are trying to come back there native place. $7 \%$ of the worker is out of money. Everything makes the migrant under psychological, social and emotional strains.

Keywords: Migration, COVID-19, Dirty, Dangerous, Demeaning, psychological
\end{abstract}

\section{INTRODUCTION}

"Human Migration" is one of the most important components of population change after fertility and mortality (Debnath, 2018). From the very beginning of human evolution, people start the migration. At that time human being was a nomad, he used to wander in different places. There was no social or economic change but there was spatial change. Over time advancement of civilization, people start to settle down at a permanent habitation. Due to the complexity of life and rapid transform of socioeconomic situation migration is gaining importance in day to day life. There is no universal definition of migration. Different scholars have tried to define the concept of migration differently. Migration refers to the mobility of people from one place to another; it may be a permanent or temporary migration, as well as a short or long term migration (Sarkar, 2017). Migration is defined broadly as a permanent or semi-permanent change of residence.
However, not all kinds of spatial mobility are included in this definition. Excluded, for example, are the continual movements of nomads and migratory workers, for whom there is no long-term residence and temporary moves like those to the mountains for the summer. (Lee) Economic factors are predominating cause of rural-urban migration (Debnath), (Basu, 2019). West Bengal ranks 28 in HDI within 36 states and union territory. It scores 0.641 which come under the medium category of Human development. Usually, migration takes place from economically less developed places to better places (Basu, 2019). However, migration is a survival strategy when economic opportunities do not favourably at home (Gosh, 2010).

Whatever most of the research on migration has been done in economic development, economic growth and employment issues (Rahamanm, 2007) rather than their family perspective and life satisfaction of their family. Although remittance income maybe increases their financial condition in their household, such a contribution should be assessed against the disruptive effect of migration on other aspects of family life (Oh, 2014). Nevertheless, it's a debatable issue for the cause of migration but recent work on migration has been done in family perspective and their life satisfaction. It seems now recent study about migration is more emphasis on life satisfaction of migrants and their family.

Life satisfaction refers to an individual's overall feelings about his or her life. Life satisfaction includes the various aspect of life like work, romantic relationships, relationships with family and friends, personal development, health and wellness, and others. Money can buy many things but not any things. Point out clearly in this current situation of the world during the pandemics of corona (COVID 19). Peoples are looking helpless in front of nature and its invisible weapon. All over the globe developed countries are in lockdown. Affected people and number of death increase at a faster rate.

At that time all people are locked in their room. Same things happen in our country also as well as our state. But at this time people who are work as unskilled or semi-skilled labour in a different part of the country as migrant labour, they are on the threat. The same thing will happen with the labours of our state West Bengal. Large numbers of people 
have migrated outside the district as well as the country also (Basu, 2019). An empirical study of Life Satisfaction and Migration Intention of Youth by Bakina shows youth those are less satisfied in their place of living they leave the place and migrate out of the city. Nearly $47 \%$ of youth change their place of residence (Bakina, 2018). Migration is a complex phenomenon that changes the culture of the society in both places of origin and destination (Hear, 2010).

It's noted that remittance can increase financial resource of a household at the same time there was a disruptive effect of migration in their family also. Only those who send large remittance they can suppress the psychological distress. Some positive side of migration also prevails like household development and development of their quality of life than non-migrants. But psychological distress of family separation is a negative side of migration (Oh, 2015).

Sarkar shows the relation of migration with urbanization. Migration increase day by day due to different causes like marriage, education, employment etc. Employment and business is the main reason for male out-migration whereas marriage is the cause of short-distance migration for female (Sarkar). The same view was given by Debnath also short distance female migration due to marriage and male outmigration for scarcity work. Rural people are more migrate because they face problems like poverty and work scarcity (Debnath, 2018). An empirical study of nature of rural unskilled labour out-migration shows the backward section of rural people are more migrated and migration is age and sex-selective. The young and middle-aged male is more migrated (Das, 2018). In our current situation pandemic, the corona is not only a health-related problem its create social problem also. UN "Department of Economic and Social Affairs Social Inclusion" address that outbreak of coronavirus affected every segment of the population. Particularly situation is worse for a vulnerable group of the population including people living in the bellow poverty line, older persons, persons with disabilities, youth, and indigenous peoples. Some evidence shows the health and economic impacts of the virus are being borne excessively by poor people.

Say, for example, homeless people it's really hard to arrange safe shelter in place, they are highly exposed to the danger of the virus. People without access to running water, refugees, migrants, or displaced persons also stand to suffer from both of the pandemic and its consequences - whether due to restricted movement, lack employment opportunities, etc. 31st December 2019 when the first case of Novel Corona virus (COVID-19) is officially detected in Wuhan of China.

Expert and scientist believed that it is the hearth of this deadliest corona virus. From Wuhan in China to the whole world everywhere the presence of this deadliest virus is the attribute of migration and mobility of the people. On the other side, medical experts are suggested that the control of this communicable disease is only possible through immobility. Epidemics have close relation with migration during the colonial period of India different communicable disease like smallpox, plague, cholera is spread by human movement. When migrants escape from the city they not only lose their livelihood but they also carry the infection to their native place (BBC 6th April 2020).

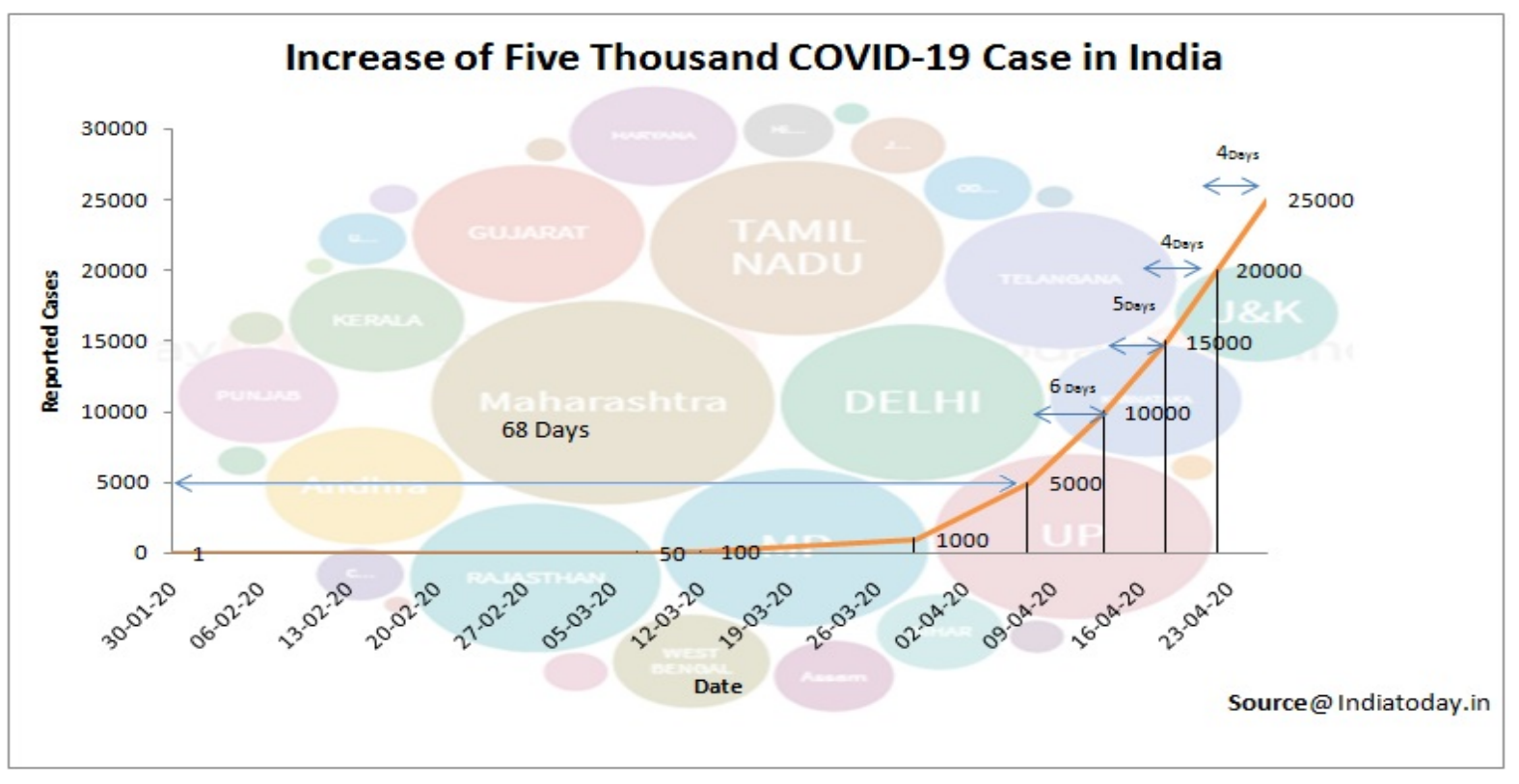

Fig.1Represent how fast COVID-19 Will Increase In India

Scientists are very little known about this new virus therefore maintain social distance is only meant to break the chain of this infection. 


\section{OBJECTIVES OF THE STUDY}

This work focused mainly on three problems of the migrant works.

1. Try to find out the crisis of workers related to their basic necessity like Food, Shelter, and Drinking water etc.

2. Try to understand how they feel in the current situation and what they try to do.

3. Attempt to identify what they want to do in this current situation.

\section{METHODOLOGY AND DATABASE}

The work is divided into seven sections. Section I deal introductory portion and analysis of empirical study related to our current study. Section II explains the objective of the study. Section III is used for showing the structure and way how this work has been done. Section IV shows how migrant worker impacts over the Indian economy. Section V shows how migrant worker is faced with different problems and intention of different local community towards them.

Section VI is an analysis of a recent secondary data of migrant workers of west Bengal over different states in India. Section VII is the final part of the work, Conclusions and different suggestion for mitigation. Data related to migration are not available properly and whatever data is available is very limited. However, data is collected from different secondary sources like different newspaper, Websites etc. We collect data of 5449 peoples of West Bengal over the different state.

We take only inter-state migration. From a secondary source of a government website, we collect the data through an active worker who manages the people and handles the data also. We use the data before $2^{\text {nd }}$ April 2020. Data represent that more than fifty per cent migrants are lives in three sate namely Mumbai (30.63), Rajasthan (17.8) and Tamil Nadu (8.17).

In addition to ninety per cent of migrants are lives within ten states including Mumbai, Rajasthan, Tamil Nadu, Kerala, Karnataka, Telengana, Delhi, Haryana, Andhra Pradesh, and Gujarat.

\section{CURRENT SCENARIO OF INDIAN ECONOMY AND MIGRANT WORKFORCE}

Within 53 Million Plus, urban areas absorbed 43 per cent of total labours of India it's equivalent to 140 million out of 377 million population. Migrant Workers are the backbone of Indian economy. 194 Million Worker out of 482 million is the permanent and semi-permanent migrant. Now nationwide lockdown for preventing the out brake millions of lives are on the threat they are engaged in the informal sector working as a casual worker. The maximum worker works on short term contracts or without any contracts. In-
Migration is higher in those places where people's income is high and labour wages are also high. While out-migration is relatively high where workers do not gate any option for employment and there has no option to the economic improvement of their life.

As per the Ministry of Statistics and Programme Implementation, 2019 report in urban area casual labour other than public works earn between Rs. 314 to Rs. 335 among males and nearly Rs. 186 to Rs. 201 among females per day during 2017-18.

\section{THE PANDEMIC COVID-19 EXPOSES DISINTERESTEDNESS TOWARDS MIGRANT WORKERS}

Migration has been playing a vital role in reshaping the socio-economic condition mostly in rural India. Usually, migration takes place from economically backward places to the better ones. In this course, the regional economic imbalance is wiped out to some extent by the movement of people (Basu, 2019).

West Bengal ranks fourth among the states from where people migrate for work and employment, the Census 2011 data reveals. Between 2001 and 2011, from West Bengal, nearly 5.8 lakh people migrated for seeking work.

Image Source: Anadabazar Patrika, 24th March
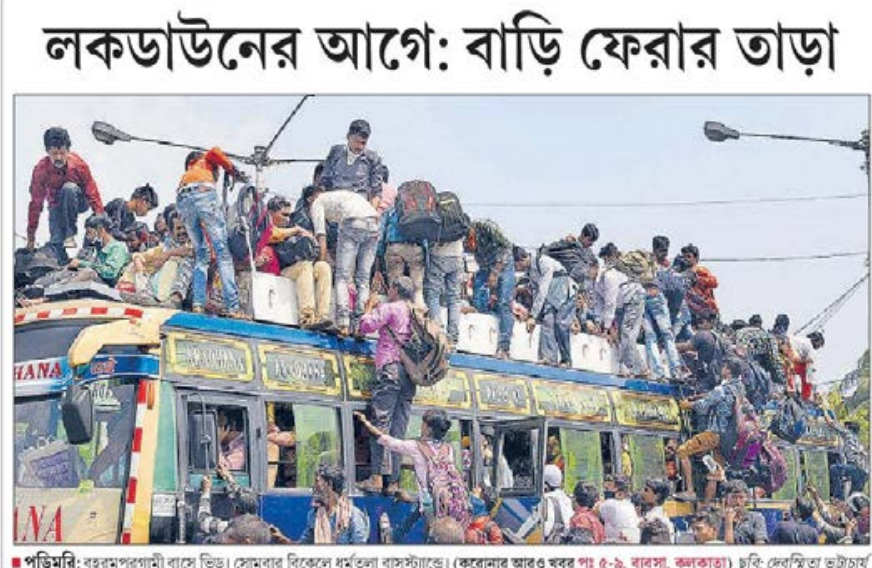

Fig.2 Before Lockdown Peoples are in a hurry to back in their home

West Bengal has a 9-crore population an estimation says from 2011 census data 2.2 lakh people, had migrated from West Bengal to other states for work and employment. Maharashtra and Delhi (NCT region) are the most favoured destinations for work for people from Bengal. As many as 45.3\% of those who migrated to Maharashtra and 34\% of those who migrated to Delhi's NCT region went for work (Times of India, 2019). On January 30, 2020, the first case of COVID-19 in India is traced. With following the outbreak from $24^{\text {th }}$ march 21 days lockdown is announced by our Prime Minister. But without any previous notice sudden lockdown is agonizing for the people those are outside of their native place. In this sudden lockdown for 
the safety of the country migrant labours are in threat. In a single announcement of lockdown hundreds of thousand migrant workers lose their job overnight and they come on the streets (Bhagat, 2020). Migrants are trying to move back their native place or return to their home. During this existing situation, all possible means of transport are closed. State border, as well as district border, is also sealed (Understanding the issues of the migrant populationCOVID-19). Fig.1, this image was taken from a renowned Bengali newspaper Anandabazar Patrika in 24.03.2020 where we see how all migrant workers are try came back in their home. There was no maintaining social distance. Everyone's life is in the threat they may be affected by the deadly virus but anyhow they try to return their home. Because they know if virus not but hunger kills.

\section{MIGRANTS AND THEIR LIFE SATISFACTION}

Unskilled and semi-skilled migrant workers are suffering from the twice burden, first of all, they are poor and migrants. Due to lack of identity and residential proof migrants are suffering in various problems in their migrated place. Lack of their identity their socio-economic and political rights are not full field (Bhagat, 2020). Generally, they are blue caller workers that are urban natives are heated to do. They engaged in 3d jobs (Dirty, dangerous and demeaning).

TABLE 1 SHOWING VARIOUS PROBLEM ARE FACED BY THE MIGRANT WORKER

\begin{tabular}{|l|c|c|c|c|}
\hline District's Name & \multicolumn{4}{|c|}{ Problems (in percentage) } \\
\hline & Insufficient Food & Monetary Problem & Get back to home & Others \\
\hline Nadia & 82.50 & 3.29 & 10.92 & 3.29 \\
\hline Malda & 78.10 & 9.77 & 7.70 & 4.43 \\
\hline North 24 Paragana & 72.73 & 5.50 & 12.92 & 8.85 \\
\hline Birbhum & 77.26 & 6.14 & 12.88 & 3.72 \\
\hline Puruliya & 70.63 & 9.17 & 13.71 & 6.50 \\
\hline Bankura & 58.76 & 9.85 & 14.47 & 16.91 \\
\hline Total & 73.33 & 7.29 & 12.10 & 7.28 \\
\hline
\end{tabular}

Migrants are less familiar with their new place where they temporarily live. They are subjected to various psychological, social and emotional strains; such problems arise from fear of ignorance by the local community and worry about Wellbeing and safety of their families waiting in their native places. In search of better opportunities and earnings, migrants are a force to leave their native places and their family.



Fig. 3 Showing various issues are faced by the Migrant Worker
During this outbreak of infectious diseases like COVID-19 some restriction are imposed in daily routine social distancing norms are used to prevent the spreading of this disease. Due to lockdown sudden stops everything except essential goods and services. All borders are sealed, Public transports are stopped and informal labours are jobless. Urgent concerns faced by such migrant workers relate to food, shelter, and healthcare, fears of getting contaminated or spreading the disease, loss of wages, and worry about the family, anxiety and fear and often they also face harassment and negative reactions of the local community (Understanding the issues of the migrant populationCOVID-19). Many people walk hundreds of miles on foot to reach their home in absence of public transport. As a consequence of potential carriers of this communicable disease those who arrived there native place they also illtreated by the villagers. From this above figure, we easily noticed that maximum migrants face great difficulty to arrange their food on an average of $73 \%$ of people faces insufficient food in their workplace during the lockdown period. During this lockdown every means of transpiration are stacked $12 \%$ of people have not accommodated them in the workplace during the current situation, they are trying to reach their motherland anyhow. Many of the people were walked or cycling hundreds of miles to reach their home. Many of them have out of money (7\%). People are getting fear they may be infected or many are faced a problem related to the room rent. Various schemes are launch to 
combat the basic problem of migrant labours by different state government nevertheless implication is not proper in the grass-root level. A report shows $96 \%$ of migrant workers did not get rations from the government, $90 \%$ did not receive wages during lockdown (The Hindu, 20.April, 2020).

\section{CONCLUSION}

In this paper, an effort has been made to give an account of vulnerability, risk and Life satisfaction of migrant worker. As per census data, 2.2 lakhs of peoples are migrated out from West Bengal. Migrant workers are suffering from the twice burden, first of all, they are poor and migrants. The maximum worker is engaged in dirty, dangerous and demeaning work. They are faced to various psychological, social and emotional strains, such problems arise fears of getting contaminated or spreading the disease, loss of wages, and worry about the family, anxiety and fear and often they also face harassment and negative reactions of the local community. Unskilled and semi-skilled migrant workers are a more vulnerable group of people. Their remittance makes their family happy and provides power to survive. But sudden the lockdown make hundreds of thousand migrant workers lose their job overnight and they come on the streets. During this lockdown without survival goods, everything is shutdown.

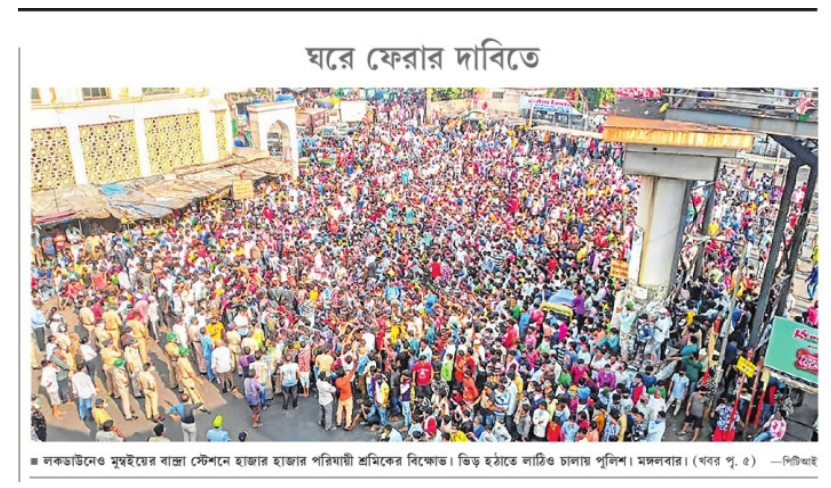

Image Source: Sangbad Pratidin, 15th April, 2019

Fig.4 Peoples showing protest for they want to go their Home

During this lockdown, every means of transpiration are stacked as per our data $12 \%$ people are trying to come back there native place. The analysis in the paper also indicates that $73 \%$ of migrant worker don't have basic food for surveillance. From various news reports that show they are within psychological and emotional strains. Many of the people were walked or cycling hundreds of miles to reach their home. Our report shows $7 \%$ of the worker is out of money. Different empirical observation and our current study easily visible to us they are not satisfied with their life due to current COVID situation. They are jobless, homeless and hopeless. They try to come back home anyhow but the way is closed. They suffer from a monetary problem. They have fears of getting contaminated from this virus. Everything makes the migrant under psychological, social and emotional strains. Various actions have been taken by the government but the implication is not done properly.

\section{লকডাউনে ভাঙা সাইকেলে বালিয়া থেকে ডোমকল এলেন আস্তাব}

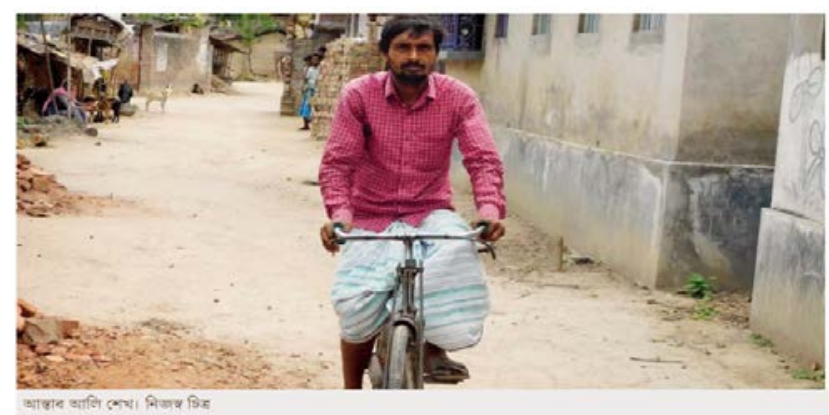

Image Source: Anandabazar Patrika, 16 ${ }^{\text {th }}$ April, 2019

Fig. 5 During the lockdown, a man paddles his cycle from Balia(UP) to Domkol(W.B.)

Therefore governments need to improve root level distribution of the government's benefits. Need for more effort by both of the government to their safety issues and try to provide various information's that helps them to get safe. Last of all everyone's duty to treat every migrant worker with dignity, respect, empathy and compassion, listen to their problems and try to resolve patiently as much as possible.

\section{REFERENCES}

[1] Ali, M. H. (2018). Causes And Consequences Of Out-Migration: A Study In Murshidabad District, West Bengal, India. International Journal of Development Research , 8 (1), 18189-18194.

[2] Anandabazar Patrika. (2020, March 24). Retrieved March 24, 2020, Retrieved from https://epaper.anandabazar.com/: https:// epaper.anandabazar.com/index.php?pagedate $=2020-3$ 24\&edcode $=71 \&$ subcode $=71 \&$ mod $=1$ \&pgnum $=1$ \&type $=\mathrm{a}$

[3] Bakina, A. V., Yaremtchuk, S. V., Orlova, O. A., \& Krasnoperova, Y. V. (2018). Life Satisfaction and Migration Intention of Youth. Advances in Economics, Business and Management Research , 47, 641-645.

[4] Basu, U. (2019). Migration Corridors: A Study on Murshidabad, West Bengal. Economic Affairs , 64 (3), 669-672.

[5] Bhagat, R. B., Reshmi, R. S., Sahoo, H., Roy, A. K., \& Govil, D. (2020). The COVID-19, Migration and Livelihood in India. International Institute for Population Sciences. International Institute for Population Sciences.

[6] Biswas, S. (2020, April 16). Anandabazar Patrika. Retrieved April 16, 2020, from https://www.anandabazar.com/: https://www.anandabazar.com/state/lockdown-in-west-bengal-astabali-reached-domkal-from-up-by-bicycle-1.1137010

[7] Das, P., \& Chouhan, P. (2008). Nature and characteristics of labour out-migration from rural Malda district, West Bengal. International Journal of Applied Social Science , 5 (8), 1141-1157.

[8] Dasgupta, A. (2010). Cross district migration of labour force in West Bengal during the post reform period. University of Calcutta, Department of Commerce.

[9] Debnath, M., \& Nayak, D. K. (2018). Male Out-Migration In West Bengal Regional Pattern and Determinants. Transactions of the Institute of Indian Geographers , 40, 119-130.

[10] Ghosh, S. (2010). Labour Out-flow and Labour Rights:A CaseStudy of West Benga. Calcutta Research group .

[11] Gutkar, N. (2014). Gender dimensions in migration: a study of Jammu region. Thesis, Veer Narmad South Gujarat University, Department of Sociology. 
[12] Hear, N. V. (2010). Theories of Migration and Social Change. Journal of Ethnic and Migration Studies , 36 (10), 1531-1536.

[13] Johri, T. (2014). Labour Migration and Risk in India. The Indian Econometric Society (TIES 2014).

[14] Kundu, S. K. (2013). Impact of Labour out-migration and Remittance on Rural areas: A Case study from West Bengal, India. Research Journal of Humanities and Social Sciences , 4 (2), 190195.

[15] Lee, E. S. (1966). A Theory of Migration. 3 (1), 47-57.

[16] Ministry of Health and Family Welfare. (2020). Understanding the issues of the migrant population- COVID-19. Government of India.

[17] Mistri, A. (2015). Estimation of Internal Migration in India, 2011 Census based on Life Table Survival Ratio (LTSR) Method. Jawaharlal Nehru University, Centre for the Study of Regional Development. Munich Personal RePEc Archive.

[18] Oh, Y. A. (2014). Life Satisfaction of the Families of Migrants in the Philippines. 3 (14), 249-271.

[19] Rahman, M. M. (2007, July). Migration and Social Development: A Family Perspective. Asia Research Institute .

[20] (2017). Risks and rewards: Outcomes of labour migration in SouthEast Asia. International Labour Organization and International Organization for Migration 2017.

[21] Rogaly, B., \& Rafique, A. (2003). Struggling to Save Cash: Seasonal Migration and Vulnerability in West Bengal, India. Development and Change , 34 (4), 659-681.

[22] Sangbad Pratidin. (2020, April 15). Retrieved April 15, 2020, from https://epaper.sangbadpratidin.in/: https://epaper.sangbadpratidin.in/epaper/edition/2329/sangbadpratidin-15-04-20

[23] Sarkar, R. (2017). Recent Changing Patterns Of Migration And Spatial Patterns Of Urbanization In West Bengal: A Demographic Analysis. South -Asian Journal of Multidisciplinary Studies , 4 (1), 46-56.

[24] Sen, S. (2019, November 3). West Bengal 4th in outbound migration for employment. Retrieved February 3, 2020, from https://timesofindia.indiatimes.com/: https://timesofindia.indiatimes.com/city/kolkata/bengal-4th-inoutbound-migration-for-employment/articleshow/71872752.cms

[25] The Hindu. (2020, April 20). Retrieved April 21, 2020, https://www.thehindu.com/data/data-96-migrant-workers-did-notget-rations-from-the-government-90-did-not-receive-wages-duringlockdown-survey/article31384413. ece 